\title{
Reconstructing the Mother-Daughter Relationship: Lydia Davis and Amy Tan
}

\author{
Hala Ewaidat \\ Department of Foreign Languages, Faculty of Education \\ Mansoura University, Egypt \\ halaewaidat@mans.edu.eg
}

Received: $12 / 18 / 2020$

Accepted: 2/8/2021

Published: 2/24/2021

\begin{abstract}
With four waves of women's liberation movements in the twentieth century, the relationship between mothers and daughters has come under increasing, frequent, intense, and passionate examination. Scholars East and West have examined this bond, giving it a universal appeal. Among the voices that have come to create speech and meaning to this relationship are. Fouad (1964), the Egyptian writer, in her book Ila Ibnaty (To My Daughter) and Rich's 1976 classic feminist work, Of Women Born: Motherhood as Experience and Institution. Concerning their definitions, this paper discusses the oppositional forms of the mother-daughter relationship in Amy Tan's Two Kinds and Lydia Davis' The Mother. In both short stories, Tan, with her Chinese traditions and American education, and Davis, whose background includes no ethnic derivations, explore the breakdown in communication in this problematic bond, aiming at reconstructing this richly influential relationship.
\end{abstract}

Key Words: ethnicity, memory, miscommunication, mother-daughter relationship, motherhood, obedience, opposition, reconstruction, suffering

Cite as: Ewaidat, H.(2021). Reconstructing the Mother-Daughter Relationship: Lydia Davis and Amy Tan. Arab World English Journal for Translation \& Literary Studies 5 (1) DOI: http://dx.doi.org/10.24093/awejtls/vol5no1.22 


\section{Reconstructing the Mother-Daughter Relationship: Lydia Davis and Amy Tan}

The mother-daughter relationship is an extraordinary bond that transcends geographical, cultural, and ethnic boundaries and unites women of every race and a historical period when they write novels, short stories, and books. This paper discusses the oppositional forms of motherdaughter relationships in Amy Tan's Two Kinds and Lydia Davis' The Mother. Through short stories, they introduced a unique examination of an intricate association in the bond between two kinds of mothers and two kinds of daughters aiming at reconstructing this relationship. In Tan's and Davis' short stories, the nature of motherhood is complex and is often obscured by sentimentality, bitterness, and pain. Mothers are alienated from their daughters, who are infuriated either because they see their mothers as pressuring them to conform to their own or society's expectations of girls and women or because they find their mothers disdaining those expectations. This anger and alienation grow not primarily from clashes between unique personalities and temperaments but rather from the external and internalized social pressures to relate and accept responsibilities to and for each other in terms of the culturally defined roles of mothers and daughters.

Motherhood and the mother-daughter relationship became the subject of literary discourse long before psychoanalytical discussion with Freud in the beginning of the twentieth century. Auerbach, (1989) noted that, in the novels of Jane Austen and other nineteenth-century womenauthors, "mothers and daughters are at best indifferent and at worst antagonistic" $(\mathrm{p}, 36)$. She pointed out that "motherhood was not merely a biological fact, but a spiritual essence inseparable from pure womanhood. . Maternity alone was the seal of respectable female maturity" (pp. 1734). Marianne Hirsch believes that "in conventional nineteenth-century plots of the European and American tradition, the fantasy that controls the female family romance is the desire for the heroine's singularity based on dis-identification from the fate of other women, especially mothers" (Mother p.10).

Scholars East and West have come to create speech and meaning to the mother-daughter relationship where there has been silence and absence. The Egyptian writer Fouaad, dedicated her book, Ila Ibnaty (To My Daughter) to her 'beloved daughter' asking her to give it to her friends, granddaughters and to "all daughters... and all mothers" (12). It won the UNESCO prize in 1964 as one of the best ten books worldwide written on motherhood and daughterhood. After 56 years the book has been perhaps her most famous and widely read; when reprinted in 1984, Amazon posted this commentary on the book: "After four decades, the book is more relevant than ever...[offering] surprisingly fresh thoughts and timeless values". This book introduces universal guiding principles for constructing the mother-daughter relationship. Fouaad, (1964) defines 'The art of motherhood' as,

a process of creation: the mother creates men and women according to her own wish and will. History tells you endless stories of men who were made great by their own parents, even if they were not that smart.. .motherhood is production not consuming. It is really a mixture of selfishness which is part of possessive instinct and altruism (unselfishness or 
self-sacrifice) related to passion. A mother is usually a giver. A mother's altruism appears in her wish to elevate her children above all even herself. (p. 151)

Thirty-four years later, Auerbach (1998) defined motherhood as the "spiritual essence of pure womanhood" (p.173 ). Fouad considers motherhood as an excess of compassion that does not stop or diminish with age, it increases to bestow a mother with sacredness. She asks her daughter to give her children compassion as long as she lives; cruelty in a mother shakes her children's values because they see evil emerging from where goodness is supposed to spring. She believes that when values are shaken a mother's throne is permanently threatened, and she can never restore it. "Nothing, then, can preserve what is left from the features of motherhood. Mothering is different, it refers to the characteristics of females of all species like labor and breast feeding". (p.152).

Fouad describes a parent's love for their children as unique in its purity and depth. Parenthood is the ultimate perfection because it is a purposeless, strong, and eternal passion that urges people to work and struggle and encourages them to be virtuous for the sake of their children. (160) Rich (1976) highlighted in her classic feminist work the serenity that has surrounded the relationship between mothers and daughters. She wrote:

This cachexia between mother and daughter essential, distorted, misused-is the great unwritten story ... that awaited analysis and definition...Probably there is nothing in human nature more resonant with charges than the flow of energy between two biologically alike bodies, one of which has lain in amniotic bliss inside the other, one of which has labored to give birth to the other. (pp. 225-226).

Hirsch, (1989) points in her review that there has been no comprehensive study that takes into account a woman's role as a mother of daughters and as a daughter of mothers or that studies female identity in relation to previous and subsequent generations of women (3). The earliest source of 'identification' for children, according to Chodorow(1989) is the mother. (pp. 78-9). As for daughters, she believes that the 'daughter continues to identify with the mother' (292), and this affects their 'interdependence and continuity' and 'the role women play in the society overall'. (p.26).

Still, many novels stem from an explicitly feminist perspective; they are undoubtedly a welcome development that forces this long-submerged relationship into the cultural spotlight. Walters (1992) points out that most of the literary works that portrayed the mother-daughter relationship have self-consciously developed oppositional forms of this relationship. Most of them fall within the dichotomous framing of bond and separate the two sides of the coin of adult development (p. 163). Prince (2020) asserts that girls find it difficult to break away from the overpowering influence of the mother. This, sometimes, hinders the girls from developing a normal sense of self, which affects their entire life.

AmyTan is one of the pioneers whose work breaks new grounds in the treatment of the mother-daughter relationship in American fiction. Through her short stories and novels, she has brought fame and recognition, presenting a new perspective to this relationship as a theme in 
American fiction. The short story Two Kinds from her book The Joy Luck Club (1989), introduces this theme which has also been explored in her novels, The Kitchen God's Wife (1991) and The Bonesetter's Daughter (2001). She investigates the nature of the struggle between Chinese mothers and their American daughters and its impact on the lives of both and the way they can resolve this problematic relationship reaching a peaceful reconciliation.

In Tan's Two Kinds, the mother, Suyuan Woo, is a Chinese immigrant who is obsessed with the idea of her daughter, Jing-Mei Woo, becoming a child prodigy. This recalls Fouaad's description of motherhood as "a process of creation: the mother creates men and women according to her own wish and will". (p. 151) With high expectations for her daughter and avid belief in the American dream, the mother tells her, "you could be anything you wanted to be in America... America was where all my mother's hopes lay (Tan 240)." The mother who encountered failure in her life strives for some sort of compensation and perfection in her daughter. As an American who believes in the freedom of choice, the daughter becomes "determined not to try, not to be anybody different (Tan 244)," because she has a different kind of personality, and she is the one to decide how to realize her own identity. The resistive daughter fails her mother's high expectations. In The Mother, Lydia Davis demonstrates an oppositional mother-daughter relationship of an authoritative mother and a daughter who fails in gaining her mother's satisfaction.

Pearlman(1989), the editor of a feminist volume analyzing fiction on mothers and daughters, proclaims in the introduction that, "[The]reality of the mother-daughter experience is that mothers are more disabling than enabling, that daughters are often more ... detached from their mothers in ways that are disturbing and dis-hearting."(7) He contends that these writers place a sort of either/or and life/death kind of emotional and psychological weight on this relationship.(8) This "disabling" mother is the protagonist of Davis's short story The Motherer, her 'micro- story' that Adams(2019)describes as "witty, playful and pared to the bare essentials". The one-paragraph short story reads as follows,

\section{The Mother}

The girl wrote a story, "But how much better it would be if you wrote a novel," said her mother. The girl built a doll-house. "But how much better if it were a real house," her mother said. The girl made a small pillow for her father. "But wouldn't a quilt be more practical," said her mother. The girl dug a small hole in the garden. "But how much better if you dug a large hole," said her mother. The girl dug a large hole and went to sleep in it. "But how much better if you slept forever,' said her mother. (96)

Instead of support and encouragement, the daughter constantly receives her mother's criticism, opposition and dissatisfaction. The daughter's actions represent her attitude to find herself. Genovese (1988) redefines the bond of mothers and daughters as an intimate relationship when they look to each other "for love, acceptance, and approval" (xvi). However, when the daughter loses her admiration for her mother, and the mother is tired of mothering, the bonds of intimacy between the two are broken. The Mother introduces in a paragraph a whole book of life

Arab World English Journal for Translation \& Literary Studies 
when the mother is tired of mothering, contradicts her role of love and guidance to her daughter. On describing the world Lydia Davis creates in her tiny short stories, Romero (2018) believes that,

The uniqueness of Lydia's astounding world lies in her way of seeing and perceiving life while making an effort to describe it carefully and with the exact amount of words... In The Mother, for example, she explains the entire essence of a complex mother-daughter relationship in just one short paragraph, and by the end we feel the daughter's pain with absolute clarity.

From the beginning, Davis foregrounds the broken relationship by using nameless characters. The word daughter is not even used, instead, she is referred to as 'the girl'. In the context of this hostile bond, only the mother's voice is heard and the daughter is silent. For many women, silence is a coping strategy - a way to avoid pain or evade confrontation. It is a technique for negotiating anguish resentment and disgrace that leads to confusion, solitude depression, and even death. Silence between mother and daughter deprives both parties of a common emotional language, rendering them virtual strangers. Becoming voiceless, a woman is not entitled of her own life and deprived of the ability to speak her story.

Silence can result from the existence of so many variations of a story that the truth is obscured or remains unsaid. In Amy Tan's Two Kinds, Jing-Mei Woo complains of her mother repeating the same story about her abandoned twins in China in various versions, "over the years she told me the same story, except for the ending, which grew darker and darker, casting long shadows into her life, and eventually into mine". The social and cultural conditioning with the mother's inability to speak the same language as her daughter result in silence, "Of course you can be prodigy, too" my mother told me when I was nine. "You can be best anything." Huntley noted that the apparent folly of Mrs. Woo's aspirations for her daughter can be learnt from her dogmatic belief that America is the 'Land of Opportunity'. She places unreasonable expectations on the shoulders of her young, tender daughter. Nevertheless, the daughter is not the same "girl" of Davis' The Mother, Jing mei disillusions her mother, "And then I decided. I didn't have to do what my mother said anymore. I wasn't her slave. This wasn't China."(p.719) This is what the author did in reality, according to Liu's words on Tan's life, "Caught in the conflicting pressure to conform to her mother's Chinese traditions and to follow the example of her Western peers, Amy Tan rebelled against whatever her mother said and expected".(p.9)

In The Mother, the unexpected, sudden and shocking ending, "evokes a note of the absurd, but also of a deep, troubling loneliness and senselessness in the worlds of Davis' characters" as Deb(2007) noted, "Mothers usually experience internal turmoil as they prepare their daughters into a hostile world". In The Mother, the daughter is the one in pain after her failure in her relationship with her mother. Her submissive, silent attitude gains the girl the reader's sympathy while depriving the mother of understanding her objections. The mother in Amy Tan's Two Kinds resorts to the silent attitude after struggling to secure a better future for her resistive daughter.

Fouad's perspective of the 'endless stories of men who were made great by their own parents, even if they were not that smart', is the goal and sole interest of the mother in Two Kinds. She motivates, provides assistance and supports her daughter to be distinguished. Willard (1989) indicates that mothers want nothing less than perfection for their daughters. That is why they 
demand perfect obedience. Willard explains that in Amy Tan's novels, the American daughter of a mother of Chinese origin, like Tan herself, is not free to fall short of their mothers expectations in this free society. Therefore, even the most successful daughters are haunted by a sense of failure, and even the most determined mothers are dismayed to find their daughters repeating their own weaknesses. Jing-mei resists all her mother's endeavors and high expectations. "At last she (her mother) was beginning to give up hope". Women sometimes use the power of motherhood to abuse, manipulate, and dominate. The daughter really felt that her mother uses the power of motherhood to abuse and decide her future identity. The mother's unceasing efforts to create a prodigy of her American-Chinese girl might be because of the lack of choice in her own life in China that causes her great suffering, misery, and grief, but the daughter understands that the power to make decisions and be only herself is her path to personal freedom. Greene (2020) interrelates the way a woman perceives herself to aspects of the oppression that she encounters in her life as the material reality of the surrounding conditions.

Firmly clinging to their memories in China even as they adapt to American culture, the mothers deliberately remain suspended between two worlds and two cultures. The daughters, on the other hand, are noticeably more American than Chinese despite their clearly Asian features, and since childhood, they have deliberately attempted to cultivate American ways and rejected much of their Chinese heritage. The daughters yearn for an Americanization that they can neither define nor describe. More than anything else, they are unhappy, unfulfilled, and uncertain about their identities, about their place in the culture that they want to claim as theirs. Jing mei knows that, "It was not the only disappointment my mother felt in me. In the years that followed, I failed her so many times, each time asserting my own will, my right to fall short of expectations. . . unlike my mother, I did not believe I could be anything I wanted to be. I could only be me".(p. 718 )

When the daughter fails, the mother has been forced to admit to herself that her dream will more than likely never find fulfillment. "And after seeing my mother's disappointed face once again, something inside of me began to die. I hated the tests, the raised hopes and failed expectations." Rashid describes Jing mei's mother as a "failure" whose mistake is enforcing not inspiring her daughter because the mother 'suffers from unknowingness', that is, a sense of loss of identity. Finally the mother compensates her own loss trying to find a prodigy in her daughter. Jing-mei says, "at first my mother thought I could be a Chinese Shirley Temple. We'd watch Shirley's old movies on TV as though they were training films. Her mother tells -Ni ken- you watch". (Tan, 1989, p.715). Going through various tests by Mrs.Woo, who expects Chinese obedience, Jing-mei reflects on free will when thinking of identity goals. The failure of the motherdaughter relationship becomes the ultimate end for the daughter's rebellion that ended with a lack of effective communication.

Tan contends that being frequently labeled an Asian American writer, this issue is not her primary driving force. Huntley quotes her saying, "I don't see myself writing about culture and the immigrant experience. That's just part of the tapestry. What my books are about is the relationship and family. I've had women come up to me and say they've felt the same way about their mothers, and they weren't immigrants." (30) The inescapable fact remains that although Tan's novels are indeed about universal concerns and commonly recognized themes, about the 
relationships and familial bonds and self and identity, they also are about the members of an ethnic minority that has over a century or more developed a distinctive diaspora culture that exists within the larger framework of cultures in the United States. In Two Kinds, when the daughter faces her mother's dream and tells her, "You want me to be someone that I'm not! I'll never be the kind of daughter you want me to be!" The mother-daughter conflict occurs when the daughter selects her own and rejects her mother's lifestyle and non-American origin. In times of crisis in the their relationship the mother's Chinese culture is present, "Only two kinds of daughters,» she shouted in Chinese. «Those who are obedient and those who follow their own mind! Only one kind of daughter can live in this house. Obedient daughter!" The major friction between Tan's mother and daughter arises from the mother's desire for her daughter to be successful by American measures while remaining culturally Chinese. In response, the daughter has-perhaps unconsciouslymanaged to subvert her mother's plans by ignoring her attempts to instill the Chinese image of the "obedient daughter" into her mind and becoming so thoroughly Americanized believing only in what she is not what she can do.

The result is a breakdown in communication between a mother and a daughter; more like enemies than friends, the two are so wary about each other that they cannot voice their frustrations and fears. Unable to communicate with her daughter, the mother swallows her sorrow and withdraws into loneliness. But before that, the mother struggles to instill in her daughter a true desire to be part of her dream; the daughter wrestles with the need to resolve the equation of her American life and freedom with the incomprehensible expectations of Chinese rooted mothers. Alienation and silence between mother and daughter now exists, intensified by a wide gulf between generations. "I won't let her change me, I promised myself. . . I won't be what I'm not . . .I'm not a genius. . . No! I said, and I now felt stronger, as if my true self had finally emerged". As a devoted mother Mrs. Woo tries to bring the best in her daughter, " but fails thoroughly in her attempt because Jing-mei comes between the socio-cultural influences of the American dream and her mother's failure. . . Jing- mei cannot cope with her mother's choice of way because she (Jing) is what she is and that is her own identity; and subjective way of thinking", as Rashid noted.

Compassionate attempts of the two generations to understand each other at the end of the story when the mother decided to give her daughter the piano telling her it's 'yours'. Tan's attitude towards this relationship changed before the mother's death, as if there seems to be some kind of maturing on the daughter's side inclining her closer to her mother. The shift mirrors the change in the writer's own perspective in the course of time towards this universal bond in later novels. Tan's fiction reveals that the writer had a complex relationship with her mother and that she needed to re-examine that bond to reach an understanding that would help her achieve meaning and sustenance. Probably one of the most adaptive responses was Tan's use of their complex relationship in developing the distinctive mother-daughter relationships that characterize her fiction.

More than once, Tan explains the biographical elements that reflect the life of her mother, Daisy Tan, who died of Alzheimer's disease. "The regrets are hers, the fear of the curse, the sense of danger she instilled in me while wanting me to have a better life. Asking forgiveness is in the book as well. That was part of saying goodbye" (Cujec 215). An emotional memory of her 
childhood rings true to the author's girlhood insecurities: "Moving to a new home eight times made her aware of how she didn't fit in". (The Bonesetter's Daughter p.54)

In Two Kinds the daughter appears to be living out the American Dream, but as the story unfolds, her dissatisfaction becomes more apparent. In the story, the dreams and ambitions of an immigrant woman who has braved the unknown and traveled across oceans in the quest for better life with limitless opportunities for her daughter. Jing mei's mother must overcome the sense that her daughter often looks at her as an outcast in America. Tan does not neglect to portray the serious dilemmas and ironies that the mother confronts in creating and maintaining a protective environment for her family in America (Ho, 2000, p.103). However, the daughter does not speak directly to her mother throughout the book because she is convinced that her mother is irrevocably disappointed in her, and certain that she can do nothing to win maternal approval or praise. Therefore, communication is almost impossible between them. She is sure of one thing of her need to an identity.

In American fiction, many works written by and for women examine the trauma of selfdiscovery and the struggle between mothers and daughters. In most known novels, writers tend to resolve the mother-daughter conflict by removing the mother either physically or emotionally. Physical separation by illness and death has existed in many novels or emotionally through dependence on alcohol or drugs. By removing the mother, these authors allow daughters more freedom to face and solve problems on their own. Tan's novels offer equal stances for both mothers and daughters to explore their memories and articulate their sorrows through storytelling. While most novels focus on one side of the struggle, which is usually the daughter's, Tan's fiction, attempts to present a balanced treatment of the theme by assembling the two sides of the story and offering them equal chances to articulate their narratives. It is this balance, an essential constituent of Chinese culture that sets Tan's approach as unique and appealing. Thus, the basis of Tan's distinct approach to the mother-daughter relationship is evident in Two Kinds as both the mother and the daughter have been offered equal chances to narrate their part of the story allowing them to reach an understanding and appreciation. "So she surprised me. A few years ago, she offered to give me the piano, for my thirtieth birthday. I had not played in all those years. I saw the offer as a sign of forgiveness, a tremendous burden removed. «Are you sure? » I asked shyly. «I mean, won't you and Dad miss it? » «No, this your piano, » she said firmly. «Always your piano. You only one can play".

Tan's approach in treating the mother-daughter relationship differs from other writers as she presents both mothers and daughters in the same context and allows each one the opportunity to articulate and voice her experiences and memories. This echoed Hirsch's words, "The story of female development, both in fiction and theory, needs to be written in the voice of mothers as well as in that of daughters. . . Only in combining both voices, in finding a double voice that would yield a multiple female consciousness, can we begin to envision ways to "live afresh" (161). In Tan's novels, as in Two Kinds, memory becomes the vehicle by which the past reconfigures the present, which the present, and through which the present revisits the past. Mother-daughter relationship is not valued on a material scale but through the sharing of endearments and advice and the passing of tender memories to the next generations of daughters. Within this problematic framework, the mother and the daughter in Tan's story struggle to maintain vital communication 
with each other and to piece together the fragmented memories through talk-stories of their actual lives. "And that's when I remembered the babies she had lost in China, the ones we never talked about". Mother'life stories, as Ho (2000) explains are "the valuable guides that help women survive with a certain amount of grace, anger, strength, connectedness, and love". (p.106).

In 2019 The Literary Hub published, Amy Tan Reflects on 30 Years since The Joy Luck Club: Writing Fiction that's Truer than Memoir. This is her comment on Two Kinds,

The characters are mothers who emigrated from China and their modern thirty-something American-born daughters. Their relationships are fraught with years of misunderstandings and accumulated pain. A mother's hopes and expectations become a daughter's sense of failure. A mother's advice is received by a daughter as rejection of who she really is. The mother, in return, feels her daughter knows nothing about her and has learned nothing from her mother, the one who loved her best.

In most American fiction, mothers are removed from the narratives resulting in an irrecoverable breakdown in the relationship between mothers and daughters. Moreover, most of these stories reflect the daughter's side of the story allowing her a greater opportunity to deserve reader's sympathy while silencing the mother. Tan's novels, on the other hand, offer equal opportunities for both to present their side of the stories reflecting on their experiences. Tan manages to achieve this purpose by creating natural, familial instances of mother-to-daughter storytelling in which women seize an opportunity to speak freely without being censored or stifled. By doing so, she allows them to build new bridges of communication and mutual understanding. Reconstructing the mother-daughter relationship is the ultimate end of her fiction.(P. )

\section{Conclusion:}

In Two Kinds and The Mother, both Amy Tan, with her Chinese traditions and American education, and Lydia Davis, whose background includes no ethnic derivations, explore issues of universal interests of which the problematic yet richly influential relationship between mothers and daughters is the most significant. In Two Kinds and The Mother, much miscommunication takes place between mothers and daughters. It is a complicated and perilous task for them to dredge up and decipher each other's personal stories, sufferings, weaknesses and ambitions, which are covered in layers of silence, secrecy, pain, and ambiguity. Like their mothers, daughters must overcome their personal anger, resentment, guilt, and fear toward their mothers.

Whether mothers and daughters come to realize their fierce love and respect for each other as friends and survivors or stay alienated, they realize that there are rich challenges and meanings embodied even in the silences, fragments, tensions, and differences. This sacred bond endures all kinds of hurt, hardships, and wounds. Characterized by passion and intensity, it could be constructed.

About the Authors:

Hala Ahmed Kamal Ewaidat is a lecturer of English Literature and Culture at the University of Mansoura, Egypt. Her PhD was the first in Egypt on English Culture concentrating on Deism and its Manifestations in the major works of: Shaftesbury, Pope, Dr. Jonson and Voltaire. She

Arab World English Journal for Translation \& Literary Studies 
has published articles on ecology and culture in Arabic Literature.

ORCID https://orcid.org/0000-0003-3177-8723

\section{References}

Adams, T. (2019). Essays by Lydia Davis review - a woman of few words well chosen. The Guardian. Available at https://www.theguardian.com/books/2019/nov/26/essays-lydiadavis-review

Auerbach, N. (1986). Romantic Imprisonment: Women and Other Glorified Outcasts. New York: Columbia UP.

Bobrow, E. (2013). Gained In Translation. Available at https://www.economist.com/1843/2013/05/21/gained-in translation https://www.1843magazine.com/content/emily-bobrow/lydia-davis-gainedtranslation/

Boyd, C. J. (1989)..Mothers and Daughters: A Discussion of Theory and Research. Journal of Marriage and Family, 51, (2), 291-301.Available at www.jstor.org/stable/352493.

Brown-Guillory, E., Ed. (1996). Women of Color: Mother-Daughter Relationships in 20thCentury Literature. Austin: University of Texas Press.

Chodorow, N. (1987). Gender Relation, and Difference in Psychoanalytic Perspective. In The Future of Difference. Alice Jardine and Hester Eisenstein, Eds. New Jersey: Rutgers University Press.

Chodorow, N. (1978) The Reproduction of Mothering: Psychoanalysis and the Sociology of Gender. Berkeley: UC Press.

Cujec, C. .(2001). Excavating Memory, Reconstructing Legacy. World I 16, ( 7), .215-223.

Deb, S. (2007). Just So Stories.NewYork Times. Available at https://www.nytimes.com/2007/05/27/books/review/Deb-html

Farsethas, A.(2015). Lydia Davis at the End of the World: On Learning Norwegian and Writing the Beauty of the Dying World Literary Hub, Available at https://lithub.com/lydia- davis- at-the-end-of-theworld/2015-4-9

Freeman, J.. (2015). Anatomy of a Commission: On Publishing Lydia Davis. Available at https://electricliterature.com/2015/11/3/anatomy-of-a-commission-on-publishing-lydiadavis/

Fox- Genovese, E . (1988). My Statue, My Self: Autobiographical Writings of Afro- American Women. In Shari Benstock (Ed.), The Private Self: Theory and Practice of Women's Autobiographical Writings. Chapel Hill, NC: University of North Carolina Press.

Goodyear, D. (2014).Long Story Short: Lydia Davis's radical fiction. Available at https://www.newyorker.com/magazine/2014/03/17/long-story-short

Hall, E.. (2003).The Art of Low-Grade Anxiety: This is Lydia

Davis. The Stranger.

https://www.thestranger.com/seattle/the-art-of-low-grade anxiety.

Hammer, S.. (1975).Daughters and Mothers, Mothers and Daughters. NewYork:Quadrangle.

Arab World English Journal for Translation \& Literary Studies 
Hirsch, M.. (1989). The Mother-Daughter Plot: Narrative, Psychoanalysis, Feminism.

Bloomington, Indianapolis: Indiana University Press.

Hirsch, M.. (1989). Spiritual Bildung: The Beautiful Soul as Paradigin. Abel,etal. 23.

Hirsch, M., Elizabeth, A.,,\& Elizabeth Langland, eds. (1983). The Voyage In: Fiction of Female Development. Hanover: UP of New England.

Ho, W. (2000)In Her Mother's House: The Politics of Asian

American Mother-daughter Writing.Lanham: AltaMira Press.

Huntley, E.D.(1998). Amy Tan: A Critical Companion. Westport,

CT: Greenwood.

Liu, Q.(2017) An ecological return to harmony in Amy Tan's novels. Literature. Université Toulouse le Mirail - Toulouse II.

Lydia D. (1983). The Collected Stories of Lydia Davis. NewYork: Picador, Farrar, Straus and Giroux.

Mars-Jones, A. (2014). Reality Is Worse, London Review,

36, (8). · Available at https://www.lrb.co.uk/the-paper/v36/n08/adam-mars-jones/realityis-w`orse-2014-4-17

Pearlman , M. (1989) Mother Puzzles: Daughters andMothers in Contemporary American Literature (Contributions in Women's Studies). New York : Greenwood Press.

Phillips, S. (1991). Beyond the Myths: Mother-Daughter Relationships in Psychology,History, Literature and Everyday Life. Sydney: Hampden Press.

Prince, D.(2020) Mother-Daughter Relationship In Marsha Norman's Play 'Night, Mother. Journal Of Critical Reviews, 7 (13), 3953-3956. Doi:10.31838/Jcr.07.13.594

Rashid, A. A. (2014)."Why don't you like me the way I am? I'm not a genius": A Mistakable Understanding of a Child Prodigy in Amy Tan's Two Kinds, the Symbolic Crisis of Identity in the Specific Contexts of the American Dream. IOSR Journal Of Humanities And Social Science (IOSR-JHSS) 19, (1), 33-36. www.iosrjournals.org. Available at http://iosrjournals.org/iosr-jhss/papers/Vol19-issue1/Version 2/F019123336.pdf

Rich, A.(1986). Of Women Born: Motherhood as Experience and Institution, New York: Norton.

Robbins, M. (2014). Review: 'Can't and Won't' by Lydia Davis. Chicago Tribune. Available at https://www.chicagotribune.com/entertainment/books/ct-xpm-2014-04-04- chi-cantand-wont-lydia-davis-20140404-story.html

Romero,S. (2018)This Writer Will Show You How An Entire Life Can Fit In One Paragraph. Culturavolectiva. Available at https://culturacolectiva.com/books/lydia-davis-shortstory-writer

Tan, A. (2019). Amy Tan Reflects on 30 Years Since The Joy Luck Club: Writing Fiction That's Truer Than Memoir. The Literary Hub, Available at https://lithub.com/amy-tanreflects-on-30-years-since-the-joy-luck-club/

Valiquette-Tessier, S., Julie, G. , Marta, Y., \& Kristel Thomassin (2019) A Literature Review of Cultural Stereotypes Associated with Motherhood and Fatherhood, Marriage \& Family Review, 55:4, 299-329, DOI: 10.1080/01494929.2018.1469567 
AWEJ for Translation \& Literary Studies Volume, 5 Number 1. February 2021

Reconstructing the Mother-Daughter Relationship: Lydia Davis and Amy Tan

Ewaidat

Vivien, N. (1992). Mothers and Daughters: The Distortion of a Relationship. Bedford: St. Martins APA Press.

Walters, S. .a. (1992). Lives Together-Worlds Apart: Mothers And Daughters In Popular Culture, Berkeley: University of California Press.

White, J. (1996).The Mother/Daughter Dilemma: The Failure of Motherhood in Wilkie Collins' The Woman in White. WILLA, Volume 7.

Willard, N.. (1989).Tiger Spirits. The Women's Review of Books, 6, 10/11, 12-12. JSTOR Available at www.jstor.org/stable/4020553. 